\section{Effects of Fertilizer Type and Rate on the Quality and Nutrient Concentrations of Three Species of Field-grown Shrubs in South Florida}

\author{
Timothy K. Broschat ${ }^{1}$
}

ADDITIONAL INDEX wORDs. bush allamanda, ixora, surinam cherry, Allamanda schottii, Ixora sp., Eugenia uniflora, principal component analysis, nitrogen, phosphorus, potassiuim, magnesium, manganese, iron

SumMary. Three species of tropical shrubs, bush allamanda (Allamanda schottii), ixora (Ixora 'Nora Grant'), and surinam cherry (Eugenia uniflora), were planted into a native sand soil and a calcareous fill soil in south Florida and were fertilized with a $24 \mathrm{~N}-0 \mathrm{P}-9.2 \mathrm{~K}(24-0-11)$ turf fertilizer or an $8 \mathrm{~N}-0 \mathrm{P}-10 \mathrm{~K}-6 \mathrm{Mg}$ plus micronutrients (8-0-12) palm fertilizer at rates of 10 or $20 \mathrm{~g}$ of nitrogen $(\mathrm{N})$ per shrub four times per year. Two additional treatments using a $0-0-13.3 \mathrm{~K}-6 \mathrm{Mg}$ plus micronutrients $(0-0-16)$ palm fertilizer were applied at equivalent rates of potassium (K) (12.5 or $25 \mathrm{~g} / \mathrm{shrub}$ of $\mathrm{K})$ to that applied in the two 8-0-12 palm fertilizer treatments. Shrub size measurements, nutrient deficiency severity ratings, number of flowers, and shrub density ratings were determined at 6 months after planting (establishment period) and at 3 years after planting (maintenance phase). Data from these measured variables were subjected to principal component analysis to obtain a single measure of overall quality, namely, the scores for each plant on the first principal component. During the establishment period, ixora fertilized with the high rate of 8-0-12 had the highest quality on the sand soil, but there were no differences among treatments on the fill soil for this species or on either soil type for allamanda and surinam cherry. After 3 years of growth, ixora showed no differences in quality on either soil in response to the fertilizer treatments. On the sand soil, allamanda receiving the high rate of 24-0-11 or the low rate of 8-0-12 had significantly higher quality than unfertilized control plants, and the low rate of 8-0-12 produced the highest quality plants on the fill soil. Surinam cherry grown on sand soil had the highest qualities when fertilized with the high rates of either 24-0-11 or 8-0-12. In general, leaf nutrient concentrations were inversely correlated with overall shrub quality, with largest, highest quality plants having the lowest nutrient concentrations because of dilution effects. However, leaf manganese (Mn) concentrations were consistently within deficiency ranges for all species under most treatments, suggesting that Mn deficiency was stunting shrub growth on both soil types.

$\mathrm{T}$ he response to fertilization of newly planted woody plants and established specimens appears to vary greatly depending on time because of transplanting, species, soil type, climate, method of application, and type of fertilizer (Struve, 2002). Fertilizer recommendations for deciduous trees or shrubs growing in loam or clay soils in temperate climates would not be expected to be appropriate for evergreen species

Fort Lauderdale Research and Education Center, University of Florida, 3205 College Avenue, Davie, FL 33314

This research was supported by the Florida Agricultural Experiment Station and by the USDA National Institute of Food and Agriculture Hatch project FLAFTL-004945

The author wishes to thank Susan Thor, Andy Fu, Monica Elliott, and Bryanna Lum for their assistance in this project.

${ }^{1}$ Corresponding author. E-mail: tkbr@ufl.edu.

doi: 10.21273/HORTTECH03742-17 growing in sand soils in subtropical climates such as that of peninsular Florida. Relatively little research has been published on fertilizer requirements of shrubs in sand soils of Florida and much of that has used chinese hibiscus (Hibiscus rosa-sinensis), a species that may be atypical for tropical and subtropical shrubs because of its high nitrogen requirements (Broschat and Moore, 2010; Gilman, 1987, 1988).

Fertilizer requirements for woody plants during the first year after transplanting may be different from that of established plants. Shober et al. (2013) found no response to $\mathrm{N}$ fertilization in indian hawthorne (Rhaphiolepis indica) or sweet viburnum (Viburnum odoratissisum) after 100 weeks or at any time before that, but did observe an increase in rose (Rosa 'Knock Out') size with increasing $\mathrm{N}$ fertilization rate. Gilman and Yeager (1990) did not notice differences in growth between fertilized and unfertilized laurel oak (Quercus laurifolia) during the short 17 month duration of their study, but did find an increase in growth with increasing $\mathrm{N}$ fertilization rates in japanese ligustrum (Ligustrum japonicum). Gilman et al. (2000) also did not observe differences among treatments in the growth of southern magnolia (Magnolia grandiflora) during the first year after planting, but treatment differences were noted after the third and fourth year. On the other hand, fertilized live oak (Quercus virginiana) was larger than unfertilized trees during the first year, a trend that continued for 4 years (Gilman et al., 2000).

Most fertilizer studies on woody plants have concentrated on $\mathrm{N}$ requirements, yet in Florida landscapes, $\mathrm{N}$ deficiency symptoms are seldom observed. Magnesium (Mg) deficiency is fairly common on such trees (Dickey, 1977), but it is not known if routine application of $\mathrm{Mg}$-containing fertilizers would result in superior growth or visual quality. Gilman et al. (2000) reported no response to applied phosphorus $(\mathrm{P})$ or $\mathrm{K}$ in live oak, but this species rarely exhibits deficiencies of any nutrient element in the landscape. Broschat et al. (2008) found no response to fertilization in pentas (Pentas lanceolata) or dwarf allamanda (Allamanda cathartica 'Hendersoni'), but nandina (Nandina domestica) grew larger with $\mathrm{N}$-containing fertilizers than unfertilized controls. Fertilizer type (turf formulation that contained mostly water

\begin{tabular}{llll}
\hline $\begin{array}{l}\text { Units } \\
\begin{array}{l}\text { To convert U.S. to SI, } \\
\text { multiply by }\end{array}\end{array}$ & U.S. unit & SI unit & $\begin{array}{l}\text { To convert SI to U.S., } \\
\text { multiply by }\end{array}$ \\
\hline 0.0929 & $\mathrm{ft}^{2}$ & $\mathrm{~m}^{2}$ & 10.7639 \\
2.54 & inch $(\mathrm{es})$ & $\mathrm{cm}$ & 0.3937 \\
4.8824 & $\mathrm{lb} / 1000 \mathrm{ft}^{2}$ & $\mathrm{~g} \cdot \mathrm{m}^{-2}$ & 0.2048 \\
28.3495 & $\mathrm{oz}$ & $\mathrm{g}$ & 0.0353 \\
$\mathrm{l}$ & $\mathrm{ppm}$ & $\mu \mathrm{g} \cdot \mathrm{g}^{-1}$ & 1
\end{tabular}


soluble $\mathrm{N}, \mathrm{P}$, and $\mathrm{K}$ or a palm formulation that contained controlled release $\mathrm{N}, \mathrm{K}$, and $\mathrm{Mg}$ plus water soluble micronutrients) made no difference.

The objective of this study was to determine how three woody shrubs commonly grown in south Florida respond to different types of fertilizer; a typical turf fertilizer that contains no $\mathrm{Mg}$ or water soluble micronutrients and two palm fertilizers that contain large amounts of $\mathrm{K}$ and $\mathrm{Mg}$ plus soluble micronutrients, and to determine if fertilizer rate was important, both during and after establishment.

\section{Materials and methods}

Shrubs grown in 10-L polypropylene containers were transplanted on 10-13 July 2013 into a Margate fine sand soil (siliceous, hyperthermic Mollic Psammaquent, $\mathrm{pH}$ 6.5) and another nearby plot having $30-40 \mathrm{~cm}$ of calcareous fill soil (mostly crushed limestone, $\mathrm{pH}$ 8.4) added to the surface in Davie, FL. The latter soil is typical of soils used for planting in street medians, highway rights-ofway, and many new commercial and residential landscapes in Florida. Physical and chemical properties of these soils are provided in Broschat (2015).

The design was split plot (two soil types) with three shrub species (bush allamanda, ixora, and surinam cherry) and seven fertilizer treatments, with eight replicate plants per species and treatment completely randomized within each soil type. Plants were spaced $8 \mathrm{ft}$ apart in all directions.

Fertilizers were applied at the time of transplanting and every 3 months thereafter. Treatments included 1) no fertilizer, 2) a $24 \mathrm{~N}-$ 0P-9.2K turf fertilizer (24-0-11; Lesco, Cleveland, $\mathrm{OH}$ ) applied at a rate of $41.7 \mathrm{~g}$ per plant, 3 ) the same turf fertilizer applied at $83.4 \mathrm{~g}$ per plant, 4) a $8 \mathrm{~N}-0 \mathrm{P}-10 \mathrm{~K}-6 \mathrm{Mg}$ palm fertilizer ( $8-0-12$; Nurserymen's Sure Gro, Vero Beach, FL) applied at $125 \mathrm{~g}$ per plant, and 5) the same palm fertilizer applied at $250 \mathrm{~g}$ per plant. The turf and palm fertilizer application rates provided equivalent amounts of $\mathrm{N}$ equal to 10 and $20 \mathrm{~g}$ per shrub $\left(2\right.$ and $\left.4 \mathrm{lb} / 1000 \mathrm{ft}^{2}\right)$ of $\mathrm{N}$ per application for the low and high rates, respectively. These high rates were used because Gilman (1988) reported that chinese hibiscus growth and quality response to $\mathrm{N}$ fertilization was still linear at $15 \mathrm{lb} / 1000 \mathrm{ft}^{2}$ of $\mathrm{N}$ per year, and it was not known how these other species would respond. Two additional treatments ( 6 and 7 ) provided equivalent $\mathrm{K}$ levels to those of treatments 4 and 5 (12.5 and 25 $\mathrm{g} /$ shrub of $\mathrm{K}$, respectively) from a $0 \mathrm{~N}-$ $0 \mathrm{P}-13.3 \mathrm{~K}-6 \mathrm{Mg}$ palm fertilizer $(0-0$ 16, Nurserymen's Sure Gro). Fifty percent of the $\mathrm{N}$ in the turf fertilizer was in controlled release form (polymercoated urea) with the remainder being water soluble (urea). Water soluble $\mathrm{K}$ was provided by potassium chloride, but $2 \%$ iron (Fe) and $1 \%$ manganese $(\mathrm{Mn})$ were in rather insoluble sucrate forms. All of the $\mathrm{N}, \mathrm{K}$, and $\mathrm{Mg}$ in the palm fertilizers were controlled release (polymer-coated urea, polymer and sulfur-coated potassium sulfate, and kieserite) and $1.25 \%$ $\mathrm{Mn}, 1.17 \% \mathrm{Fe}, 0.15 \%$ zinc $(\mathrm{Zn}), 0.06 \%$ copper $(\mathrm{Cu})$, and $0.6 \%$ boron $(\mathrm{B})$ were provided by manganese sulfate, iron sulfate, iron ethylenediaminetetraacetate (EDTA), iron diaminetriaminepentaacetate (DTPA), zinc sulfate, copper sulfate, and sodium borate. All fertilizers were applied by broadcasting uniformly over a $1 \mathrm{~m}^{2}$-area surrounding each plant.

All shrubs received $\approx 2 \mathrm{~cm}$ of water from overhead irrigation three times per week during the first 6 months and twice per week thereafter. An area of $\approx 1 \mathrm{~m}^{2}$ around all shrubs was kept weed-free with glyphosate. All shrubs were measured at the time of transplanting and every year thereafter for total height and width in two opposite directions (within and across rows). The two width measurements and total height were multiplied together and the total divided by 10,000 to obtain a single size value. Growth was calculated as the size at the end of 6 months (establishment period) minus initial size. Growth during the maintenance phase was calculated as the final size after 2.5 years minus the size at the end of the establishment phase. At the time these measurements were taken, all shrubs were subjectively rated for severity of $\mathrm{N}, \mathrm{P}, \mathrm{K}, \mathrm{Mg}, \mathrm{Fe}$, and $\mathrm{Mn}$ deficiencies on a scale of 1 to 5 with a rating of 1 being severe and 5 being completely free of deficiency symptoms for that element. The deficiency severity ratings for each of these elements were averaged for each plant to obtain a single nutrient deficiency rating score. Shrubs were similarly rated on a 1 to 5 scale for relative density. Inflorescences were also counted for each plant.

Because plant quality variables such as height, widths, shrub density, and nutrient deficiency severity ratings are typically highly intercorrelated, principal component analysis was performed on the data to reduce the four original variables to a single index of overall quality, namely, the scores on the first principal component (Broschat, 1979). All quality data were standardized to a mean of 0 and a SD of 1 to eliminate the effects of differences in scale among the original variables using PROC STANDARD (SAS version 9.4; SAS Institute, Cary, NC). Principal component analysis was done using PROC PRINCOMP with scoring by PROC SCORE. In this analysis, the first principal component typically contains high positive correlations for most or all of the original variables with the first principal component, making it a useful index of overall quality. Scores for each shrub on the first principal component were further subjected to analysis of variance (ANOVA) (PROC GLM) with mean separation by the Waller-Duncan $k$-ratio method $(P=0.05)$ to determine treatment effects. Because soil type was found to have a significant effect on plant quality scores for all three species, data from each soil type were analyzed independently.

At the end of the experiment ( 10 Oct. 2015), leaf samples consisting of the youngest fully expanded leaves on each shoot were collected from each shrub for nutrient analysis. Unwashed leaf samples were dried, ground, digested using a modified Kjeldahl procedure (Hach et al., 1987), and analyzed for $\mathrm{N}$ using an autoanalyzer (Seal Analytical, Mequon, WI), P by the ascorbic acid method (Kuo, 1996), and $\mathrm{K}, \mathrm{Mg}, \mathrm{Fe}$, and $\mathrm{Mn}$ by atomic absorption spectroscopy (PerkinElmer, Waltham, MA). Leaf nutrient concentration data for each element were analyzed using ANOVA with mean separations by the Waller-Duncan $k$-ratio method.

\section{Results and discussion}

A summary of the principal component analyses showed that all plant quality variables had high positive correlations with the first principal 
component, which typically accounted for about half or more of the variation included in the original four variables (Table 1). For surinam cherry and ixora, shrub density was uniform among plants, and there were no flowers at the time of evaluation on the surinam cherries so these variables were excluded from the principal component analysis. For all three species, the first principal component accounted for more than half of the total variance of the original variables.

At the end of the 6-month establishment period, there were differences in overall quality among treatments only for ixora on the sand soil and surinam cherry on the fill soil (Table 2). In both cases it was one of the 8-0-12 treatments that resulted

Table 1. Eigenvectors or correlations of original plant quality variables with the first principal component for three species of shrubs grown in two soil types and fertilized with two rates of one turf and two palm fertilizers $(n=112)$.

\begin{tabular}{lccc}
\hline Variable & Allamanda & Ixora & Surinam cherry \\
\hline Size & 0.532 & 0.616 & 0.707 \\
Nutrient deficiency rating & 0.409 & 0.422 & 0.707 \\
Flower number & 0.540 & 0.665 & $\mathrm{n} / \mathrm{a}^{\mathrm{z}}$ \\
Density & 0.508 & $\mathrm{n} / \mathrm{a}$ & $\mathrm{n} / \mathrm{a}$ \\
Eigenvalue & 1.717 & 1.67 & 1.351 \\
Proportion of variance & 0.657 & 0.557 & 0.676 \\
\hline
\end{tabular}

${ }^{\mathrm{z}}$ Variable was not included in principal component analysis because it did not vary within this species.

Table 2. Overall plant quality (scores on the first principal component) of shrubs after 6-month establishment period on two soil types with two rates of turf and palm fertilizers $(n=8)$.

\begin{tabular}{|c|c|c|c|c|c|}
\hline Soil type & Fertilizer $^{\mathrm{z}}$ & Rate $\left(\mathrm{g} \cdot \mathrm{m}^{-2}\right)^{\mathrm{y}}$ & Allamanda & Ixora & Surinam cherry \\
\hline \multirow[t]{7}{*}{ Sand } & None & 0.0 & 3.63 & $3.64 c^{x}$ & 3.48 \\
\hline & $24-0-11$ & 41.7 & 3.01 & $4.12 \mathrm{abc}$ & 3.52 \\
\hline & $24-0-11$ & 83.4 & 4.47 & $4.32 \mathrm{ab}$ & 3.52 \\
\hline & $8-0-12$ & 125.0 & 5.18 & $4.01 \mathrm{bc}$ & 3.52 \\
\hline & $8-0-12$ & 250.0 & 3.32 & $4.56 \mathrm{a}$ & 3.51 \\
\hline & $0-0-16$ & 94.0 & 3.29 & $3.87 \mathrm{bc}$ & 3.49 \\
\hline & $0-0-16$ & 188.0 & 2.15 & $3.87 \mathrm{bc}$ & 3.45 \\
\hline$P$ value & & & $\mathrm{NS}^{\mathrm{w}}$ & 0.0097 & NS \\
\hline \multirow[t]{7}{*}{ Calcareous fill } & None & 0.0 & 2.74 & 3.61 & $3.45 \mathrm{ab}$ \\
\hline & $24-0-11$ & 41.7 & 2.76 & 3.87 & $3.53 \mathrm{ab}$ \\
\hline & $24-0-11$ & 83.4 & 3.45 & 3.80 & $3.50 \mathrm{ab}$ \\
\hline & 8-0-12 & 125.0 & 2.65 & 3.78 & $3.54 \mathrm{a}$ \\
\hline & $8-0-12$ & 250.0 & 2.06 & 3.90 & $3.47 \mathrm{ab}$ \\
\hline & $0-0-16$ & 94.0 & 2.41 & 3.65 & $3.44 \mathrm{~b}$ \\
\hline & $0-0-16$ & 188.0 & 1.75 & 3.80 & $3.43 \mathrm{~b}$ \\
\hline$P$ value & & & NS & NS & 0.0412 \\
\hline
\end{tabular}

${ }^{\mathrm{z}} 24-0-11$ [4N-0P-9.2K contains mostly water soluble nitrogen $(\mathrm{N})$ and potassium $(\mathrm{K})$ plus insoluble iron $(\mathrm{Fe})$ and manganese $(\mathrm{Mn})$, but no magnesium $(\mathrm{Mg})] ; 8-0-12[8 \mathrm{~N}-0 \mathrm{P}-10 \mathrm{~K}-4 \mathrm{Mg}$ contains controlled release $\mathrm{N}, \mathrm{K}$, and $\mathrm{Mg}$ plus water soluble micronutrients]; $0 \mathrm{~N}-0 \mathrm{P}-13.3 \mathrm{~K}-6 \mathrm{Mg}$ contains controlled release $\mathrm{K}$ and $\mathrm{Mg}$ plus water soluble micronutrients.

${ }^{\mathrm{y}} 1 \mathrm{~g} \cdot \mathrm{m}^{-2}=0.2048 \mathrm{lb} / 1000 \mathrm{ft}^{2}$.

${ }^{x}$ Means followed by different letters are significantly different at $P<0.05$ level using the Waller-Duncan $k$-ratio method.

${ }^{\mathrm{w}}$ Nonsignificant $(P>0.05)$.
6 months suggests that insufficient growth had occurred during that short time for statistically significant differences in plant quality to have developed. Alternatively, there may have been sufficient residual controlled release fertilizer in the containers at the time of transplanting to sustain plant growth and quality until the root system had extended beyond the original container volume. Broschat and Moore (2010) showed inconsistent or no responses to fertilizer type and $\mathrm{N}$ rate in chinese hibiscus during the first 6 months after transplanting on similar soils.

Overall quality of ixora at the end of the study did not differ among fertilizer treatments (Table 3). Although individual plants typically showed moderate to severe stunting and deficiency symptoms of $\mathrm{N}, \mathrm{P}, \mathrm{K}$, $\mathrm{Mg}, \mathrm{Fe}$, and $\mathrm{Mn}$ on both soils, these effects were not consistently associated with any particular treatment. When the measured plant quality variables were analyzed individually (without principal component analysis), treatment differences were noted only for $\mathrm{N}, \mathrm{Mg}, \mathrm{Mn}$, and Fe deficiency ratings on the sand soil (data not shown). In that case, the two rates of 8-0-12 palm fertilizer resulted in the fewest nutrient deficiency symptoms, whereas the untreated controls and low rate of 24-0-11 turf fertilizer resulted in the most severe nutrient deficiencies.

Fertilizer treatments significantly affected the plant quality of allamanda on both soil types (Table 3 ). In both cases, the low rate of 8-0-12 resulted in the highest plant quality scores and the unfertilized controls the lowest. On the fill soil, the low rate of 24-011 and both rates of $0-0-16$ had equally low quality scores. These data suggest that some $\mathrm{N}$ is necessary for allamanda growing on these two soil types in south Florida, but when $\mathrm{N}$ is provided some additional $\mathrm{K}$ may also be needed. However, $\mathrm{K}, \mathrm{Mg}$, and micronutrients, in the absence of $\mathrm{N}$, were not effective in improving allamanda quality, particularly on the fill soil. Some N, from either a high $\mathrm{N}$ turf fertilizer or a palm type fertilizer, was also found to improve $\mathrm{N}$ deficiency rating, but not plant size, in dwarf allamanda, a related species on the same sand soil (Broschat et al., 2008). On the other hand, some N, from either a turf or palm fertilizer, 
increased both plant size and Fe deficiency ratings in nandina (Nandina domestica) on a Bonneau fine sand soil in north Florida (Broschat et al., 2008).

Surinam cherry seemed to respond strongly to $\mathrm{N}$ application rate, with the high rate of 24-0-11 resulting in the highest quality on both soil types (Table 3 ). On the sand soil, the equivalent high $\mathrm{N}$ rate from 8 to $0-12$ produced similarly high quality plants. The no $\mathrm{N}$ treatments consistently produced the poorest quality plants in this species. Gilman (1988) also found a positive relationship

Table 3. Overall plant quality (plant scores on the first principal component) of shrubs grown on two soil types and fertilized with two rates of turf and palm fertilizers at the end of 3 years $(n=8)$.

\begin{tabular}{|c|c|c|c|c|c|}
\hline Soil type & Fertilizer $^{\mathrm{z}}$ & Rate $\left(\mathrm{g} \cdot \mathrm{m}^{-2}\right)^{\mathrm{y}}$ & Allamanda & Ixora & Surinam cherry \\
\hline \multirow[t]{7}{*}{ Sand } & None & 0.00 & $-4.72 b^{x}$ & 14.22 & $25.44 \mathrm{~b}$ \\
\hline & $24-0-11$ & 41.70 & $32.82 \mathrm{ab}$ & 17.4 & $71.49 \mathrm{ab}$ \\
\hline & $24-0-11$ & 83.40 & $52.18 \mathrm{a}$ & 19.07 & $108.99 \mathrm{a}$ \\
\hline & $8-0-12$ & 125.00 & $70.55 \mathrm{a}$ & 13.8 & $68.95 \mathrm{ab}$ \\
\hline & $8-0-12$ & 250.00 & $39.80 \mathrm{ab}$ & 21.23 & $108.22 \mathrm{a}$ \\
\hline & $0-0-16$ & 94.00 & $21.44 \mathrm{ab}$ & 14.8 & $21.64 \mathrm{ab}$ \\
\hline & $0-0-16$ & 188.00 & $21.54 \mathrm{ab}$ & 15.04 & $64.44 \mathrm{ab}$ \\
\hline$P$ value & & & 0.0417 & $\mathrm{NS}^{\mathrm{w}}$ & 0.003 \\
\hline \multirow[t]{7}{*}{ Calcareous fill } & None & 0.00 & $-3.75 c$ & 9.41 & $12.34 \mathrm{~b}$ \\
\hline & $24-0-11$ & 41.70 & $8.41 \mathrm{bc}$ & 14.58 & $76.35 \mathrm{~b}$ \\
\hline & $24-0-11$ & 83.40 & $22.28 \mathrm{ab}$ & 14.89 & $188.68 \mathrm{a}$ \\
\hline & $8-0-12$ & 125.00 & $35.57 \mathrm{a}$ & 19.27 & $56.88 \mathrm{~b}$ \\
\hline & $8-0-12$ & 250.00 & $19.12 \mathrm{ab}$ & 17.03 & $96.50 \mathrm{~b}$ \\
\hline & $0-0-16$ & 94.00 & $9.78 \mathrm{bc}$ & 10.84 & $13.64 \mathrm{~b}$ \\
\hline & $0-0-16$ & 188.00 & $1.54 \mathrm{bc}$ & 10.33 & $16.01 \mathrm{~b}$ \\
\hline$P$ value & & & 0.0067 & NS & 0.0008 \\
\hline
\end{tabular}

${ }^{\mathrm{z}} 24-0-11$ [ $4 \mathrm{~N}-0 \mathrm{P}-9.2 \mathrm{~K}$ contains mostly water soluble nitrogen $(\mathrm{N})$ and potassium $(\mathrm{K})$ plus insoluble iron $(\mathrm{Fe})$ and manganese $(\mathrm{Mn})$, but no magnesium $(\mathrm{Mg})] ; 8-0-12[8 \mathrm{~N}-0 \mathrm{P}-10 \mathrm{~K}-4 \mathrm{Mg}$ contains controlled release $\mathrm{N}, \mathrm{K}$, and $\mathrm{Mg}$ plus water soluble micronutrients]; $0 \mathrm{~N}-0 \mathrm{P}-13.3 \mathrm{~K}-6 \mathrm{Mg}$ contains controlled release $\mathrm{K}$ and $\mathrm{Mg}$ plus water soluble micronutrients.

${ }^{\mathrm{y}} \mathrm{l} \mathrm{g} \cdot \mathrm{m}^{-2}=0.2048 \mathrm{lb} / 1000 \mathrm{ft}^{2}$

${ }^{x}$ Means followed by different letters are significantly different at $P<0.05$ level using the Waller-Duncan $k$-ratio method.

${ }^{\text {w}}$ Nonsignificant $(P>0.05)$.

between $\mathrm{N}$ application rate and plant size and color in chinese hibiscus.

Fertilizer treatment affected foliar nutrient concentrations, but not in the same manner as plant quality. In allamanda, the highest quality treatments (the low rate of 8-0-12 and high rate of 24-0-11) also had lower nutrient concentrations for several elements (Table 4). Similarly, the poorest quality plants (controls) tended to have the highest nutrient concentrations for elements such as $\mathrm{N}, \mathrm{P}$, and $\mathrm{Mg}$. The negative correlations between overall plant quality and $\mathrm{Mg}$ concentrations in this species were statistically significant $(r=$ $-0.363, P=0.017$ and $r=-0.300$, $P=0.05$ for the sand and fill soils, respectively). These trends can be attributed to dilution effects in the plant tissue. Foliar Fe concentrations were unaffected by fertilizer treatment and are often poorly correlated with plant quality (Mills and Jones, 1996).

In allamanda grown on fill soil, leaf $\mathrm{P}$ concentrations were lowest for those treatments that contained $\mathrm{N}$ (both rates of 24-0-11 and 8-0-12) (Table 4). Foliar Mg concentrations were highest on treatments producing the smallest plants on both soil types (unfertilized controls) because of dilution. Manganese concentrations in allamanda were extremely low for all treatments except for the

Table 4. Leaf nutrient concentrations of nitrogen $(\mathrm{N})$, phosphorus $(\mathrm{P})$, potassium $(\mathrm{K})$, magnesium $(\mathrm{Mg})$, manganese $(\mathrm{Mn})$, and iron $(\mathrm{Fe})$ of allamanda grown in two soil types with two rates of turf and palm fertilizers at the end of 3 years $(n=6)$.

\begin{tabular}{|c|c|c|c|c|c|c|c|c|}
\hline Soil & Fertilizer $^{\mathrm{z}}$ & Rate $\left(g \cdot \mathrm{m}^{-2}\right)^{\mathrm{y}}$ & $\mathbf{N}(\%)$ & $\mathbf{P}(\%)$ & K (\%) & $\operatorname{Mg}(\%)$ & $\operatorname{Mn}\left(\mu \mathrm{g} \cdot \mathrm{g}^{-1}\right)^{\mathrm{y}}$ & $\mathrm{Fe}\left(\mu \mathrm{g} \cdot \mathrm{g}^{-1}\right)$ \\
\hline \multirow[t]{5}{*}{ Sand } & None & 0 & $2.26 \mathrm{a}^{\mathrm{x}}$ & $0.170 \mathrm{a}$ & 1.47 & $0.406 \mathrm{a}$ & $2.48 c$ & 59.2 \\
\hline & $24-0-11$ & 41.7 & $2.36 \mathrm{a}$ & $0.151 \mathrm{ab}$ & 1.88 & $0.221 \mathrm{c}$ & $15.36 \mathrm{bc}$ & 51.3 \\
\hline & 8-0-12 & 125 & $1.98 \mathrm{ab}$ & $0.106 \mathrm{~b}$ & 1.63 & $0.164 \mathrm{e}$ & $59.97 \mathrm{~b}$ & 53.5 \\
\hline & $8-0-12$ & 250 & $2.18 \mathrm{ab}$ & $0.119 \mathrm{ab}$ & 2.02 & $0.211 \mathrm{~cd}$ & $166.08 \mathrm{a}$ & 53.0 \\
\hline & $0-0-16$ & 94 & $1.92 \mathrm{ab}$ & $0.139 \mathrm{ab}$ & 1.64 & $0.226 \mathrm{c}$ & $19.37 \mathrm{bc}$ & 58.1 \\
\hline \multirow[t]{6}{*}{ Calcareous fill } & None & 0 & $1.86 \mathrm{abc}$ & $0.252 \mathrm{a}$ & $1.74 \mathrm{bc}$ & $0.372 \mathrm{a}$ & $\mathrm{bdl}^{\mathrm{v}}$ & 42.8 \\
\hline & $24-0-11$ & 41.7 & $1.56 \mathrm{c}$ & $0.112 \mathrm{de}$ & $1.16 \mathrm{c}$ & $0.245 \mathrm{~b}$ & $11.72 \mathrm{bc}$ & 59.3 \\
\hline & $24-0-11$ & 83.4 & $2.13 \mathrm{a}$ & $0.144 \mathrm{~cd}$ & $1.76 \mathrm{abc}$ & $0.227 \mathrm{~b}$ & $7.31 \mathrm{c}$ & 53.2 \\
\hline & 8-0-12 & 125 & $1.79 \mathrm{bc}$ & $0.101 \mathrm{de}$ & $1.98 \mathrm{ab}$ & $0.153 \mathrm{c}$ & $53.17 \mathrm{ab}$ & 51.3 \\
\hline & $8-0-12$ & 250 & $1.95 \mathrm{ab}$ & $0.098 \mathrm{e}$ & $2.35 \mathrm{ab}$ & $0.201 \mathrm{bc}$ & $56.24 \mathrm{a}$ & 54.6 \\
\hline & $0-0-16$ & 94 & $1.59 \mathrm{c}$ & $0.158 \mathrm{bc}$ & $2.10 \mathrm{ab}$ & $0.205 \mathrm{bc}$ & $14.27 \mathrm{bc}$ & 54.8 \\
\hline
\end{tabular}

${ }^{\mathrm{z}} 24-0-1 \mathrm{l}(24 \mathrm{~N}-0 \mathrm{P}-9.2 \mathrm{~K}$ contains mostly water soluble $\mathrm{N}$ and $\mathrm{K}$ plus insoluble Fe and $\mathrm{Mn}$, but no $\mathrm{Mg}$ or micronutrients); 8-0-12 (8N-0P-10K-4Mg contains controlled release $\mathrm{N}, \mathrm{K}$, and $\mathrm{Mg}$ plus water soluble micronutrients); $0-0-16(0 \mathrm{~N}-0 \mathrm{P}-13.3 \mathrm{~K}-6 \mathrm{Mg}$ contains controlled release $\mathrm{K}$ and $\mathrm{Mg}$ plus water soluble micronutrients).

${ }^{\mathrm{y}} \mathrm{l} \mathrm{g} \cdot \mathrm{m}^{-2}=0.2048 \mathrm{lb} / 1000 \mathrm{ft}^{2}, \mathrm{l} \mu \mathrm{g} \cdot \mathrm{g}^{-1}=1 \mathrm{ppm}$.

${ }^{\mathrm{x}}$ Means followed by different letters are significantly different at $P<0.05$ level using the Waller-Duncan $k$-ratio method

"Nonsignificant at $P>0.05$.

${ }^{\vee}$ Below detection limits for method. 
two 8-0-12 treatments. Concentrations below $50 \mu \mathrm{g} \cdot \mathrm{g}^{-1}$ are considered to be low (Jones et al., 1991) and Mn deficiency likely caused stunting in plants receiving other treatments. This stunting from $\mathrm{Mn}$ deficiency may have been responsible for the elevated concentrations of other elements on the smallest plants. Manganese deficiency rating was the only plant quality variable that was negatively correlated with plant size and all other plant quality variables (data not shown). Foliar Mn concentrations in dwarf allamanda were similarly found to be highest in plants fertilized with palm fertilizers that contained $1 \%$ to 2\% Mn (Broschat et al., 2008).

Although ixora quality was unaffected by fertilizer treatment, leaf nutrient concentrations of all elements except $\mathrm{N}$ and Fe differed significantly among treatments on both soil types (Table 5). Phosphorus concentrations tended to be lowest in those treatments that contained $\mathrm{N}$ and produced slightly larger plants, whereas $\mathrm{K}$ concentrations were highest in the treatments that contained large amounts of $\mathrm{K}$ (both rates of 8-0-12 and 0-0-16). Foliar Mg concentrations were lowest for those treatments having high rates of $\mathrm{N}$ or high $\mathrm{N}: \mathrm{Mg}$ ratios (high rate of $8-0-12$ and both rates of 24-0-11). As with allamanda, ixora $\mathrm{Mn}$ concentrations were

Table 5. Leaf nutrient concentrations of nitrogen $(\mathrm{N})$, phosphorus $(\mathrm{P})$, potassium $(\mathrm{K})$, magnesium $(\mathrm{Mg})$, manganese $(\mathrm{Mn})$, and iron (Fe) of ixora grown in two soil types with two rates of turf and palm fertilizers at the end of 3 years $(n=6)$.

\begin{tabular}{|c|c|c|c|c|c|c|c|c|}
\hline Soil & Fertilizer $^{\mathrm{z}}$ & Rate $\left(\mathrm{g} \cdot \mathrm{m}^{-2}\right)^{\mathrm{y}}$ & N (\%) & $\mathrm{P}(\%)$ & $\mathrm{K}(\%)$ & $\operatorname{Mg}(\%)$ & $\operatorname{Mn}\left(\mu \mathrm{g} \cdot \mathrm{g}^{-1}\right)^{\mathrm{y}}$ & $\mathrm{Fe}\left(\mu \mathrm{g} \cdot \mathrm{g}^{-1}\right)$ \\
\hline \multirow[t]{6}{*}{ Sand } & None & 0 & 1.30 & $0.173 \mathrm{~b}^{\mathrm{x}}$ & $1.23 \mathrm{c}$ & $0.327 \mathrm{a}$ & $2.37 \mathrm{~d}$ & 85.3 \\
\hline & $24-0-11$ & 41.7 & 1.20 & $0.082 \mathrm{~cd}$ & $1.13 \mathrm{c}$ & $0.270 \mathrm{bc}$ & $3.93 \mathrm{~cd}$ & 83.7 \\
\hline & $24-0-11$ & 83.4 & 1.15 & $0.065 \mathrm{~d}$ & $1.24 \mathrm{c}$ & $0.234 \mathrm{c}$ & $8.07 \mathrm{bc}$ & 84.3 \\
\hline & $8-0-12$ & 125 & 1.15 & $0.106 \mathrm{c}$ & $1.56 \mathrm{~b}$ & $0.283 \mathrm{ab}$ & $11.93 \mathrm{~b}$ & 75.6 \\
\hline & $8-0-12$ & 250 & 1.17 & $0.101 \mathrm{c}$ & $1.80 \mathrm{ab}$ & $0.272 \mathrm{bc}$ & $16.48 \mathrm{a}$ & 67.4 \\
\hline & $0-0-16$ & 94 & 1.20 & $0.179 \mathrm{~b}$ & $1.76 \mathrm{ab}$ & $0.294 \mathrm{ab}$ & $5.07 \mathrm{~cd}$ & 96.8 \\
\hline \multirow[t]{6}{*}{ Calcareous fill } & None & 0 & 1.21 & $0.241 \mathrm{a}$ & $1.36 \mathrm{bc}$ & $0.350 \mathrm{a}$ & $2.63 c$ & 84.8 \\
\hline & $24-0-11$ & 41.7 & 1.11 & $0.095 \mathrm{~b}$ & $1.00 \mathrm{c}$ & $0.316 \mathrm{a}$ & $3.94 \mathrm{bc}$ & 99.2 \\
\hline & $24-0-11$ & 83.4 & 1.93 & $0.066 \mathrm{~b}$ & $1.14 \mathrm{c}$ & $0.242 \mathrm{~b}$ & $4.66 \mathrm{~b}$ & 100.0 \\
\hline & $8-0-12$ & 125 & 1.72 & $0.115 \mathrm{~b}$ & $1.59 \mathrm{ab}$ & $0.341 \mathrm{a}$ & $5.31 \mathrm{ab}$ & 90.9 \\
\hline & $8-0-12$ & 250 & 1.52 & $0.097 \mathrm{~b}$ & $1.73 \mathrm{ab}$ & $0.300 \mathrm{ab}$ & $6.68 \mathrm{a}$ & 85.5 \\
\hline & $0-0-16$ & 94 & 1.25 & $0.222 \mathrm{a}$ & $1.85 \mathrm{a}$ & $0.320 \mathrm{a}$ & $4.90 \mathrm{ab}$ & 107.1 \\
\hline
\end{tabular}

${ }^{\mathrm{z}} 24-0-11$ (24N-0P-9.2K contains mostly water soluble $\mathrm{N}$ and $\mathrm{K}$ plus insoluble Fe and $\mathrm{Mn}$, but no Mg or micronutrients); 8-0-12 (8N-0P-10K-4Mg contains controlled release $\mathrm{N}, \mathrm{K}$, and $\mathrm{Mg}$ plus water soluble micronutrients); 0-0-16 (0N-0P-13.3K-6Mg contains controlled release $\mathrm{K}$ and $\mathrm{Mg}$ plus water soluble micronutrients $]$.

${ }^{\mathrm{y}} 1 \mathrm{~g} \cdot \mathrm{m}^{-2}=0.2048 \mathrm{lb} / 1000 \mathrm{ft}^{2}, \mathrm{l} \mu \mathrm{g} \cdot \mathrm{g}^{-1}=1 \mathrm{ppm}$.

${ }^{\mathrm{x}}$ Means followed by different letters are significantly different at $P<0.05$ level using the Waller-Duncan $k$-ratio method.

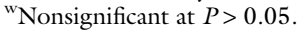

Table 6. Leaf nutrient concentrations of nitrogen $(\mathrm{N})$, phosphorus $(\mathrm{P})$, potassium $(\mathrm{K})$, magnesium $(\mathrm{Mg})$, manganese $(\mathrm{Mn})$, and iron $(\mathrm{Fe})$ of surinam cherry grown in two soil types with two rates of turf and palm fertilizers at the end of 3 years $(n=6)$.

\begin{tabular}{|c|c|c|c|c|c|c|c|c|}
\hline Soil & Fertilizer $^{\mathrm{z}}$ & Rate $\left(\mathrm{g} \cdot \mathrm{m}^{-2}\right)^{\mathrm{y}}$ & N (\%) & $\mathbf{P}(\%)$ & K (\%) & $\operatorname{Mg}(\%)$ & $\operatorname{Mn}\left(\mu g \cdot g^{-1}\right)^{y}$ & $\mathrm{Fe}\left(\mu \mathrm{g} \cdot \mathrm{g}^{-1}\right)$ \\
\hline \multirow[t]{6}{*}{ Sand } & None & 0 & $1.68 \mathrm{a}^{\mathrm{x}}$ & $0.310 \mathrm{a}$ & $1.13 \mathrm{bc}$ & 0.254 & $4.63 \mathrm{~d}$ & 72.7 \\
\hline & $24-0-11$ & 41.7 & $1.37 \mathrm{bcd}$ & $0.213 \mathrm{bc}$ & $0.98 \mathrm{c}$ & 0.216 & $7.90 \mathrm{~cd}$ & 68.6 \\
\hline & $24-0-11$ & 83.4 & $1.40 \mathrm{bcd}$ & $0.164 \mathrm{c}$ & $0.96 \mathrm{c}$ & 0.207 & $14.17 \mathrm{~b}$ & 61.4 \\
\hline & 8-0-12 & 125 & $1.34 \mathrm{~cd}$ & $0.193 \mathrm{c}$ & $1.10 \mathrm{bc}$ & 0.220 & $13.39 \mathrm{bc}$ & 71.8 \\
\hline & $8-0-12$ & 250 & $1.26 \mathrm{~d}$ & $0.159 \mathrm{c}$ & $1.25 \mathrm{~b}$ & 0.193 & $22.52 \mathrm{a}$ & 67.7 \\
\hline & $0-0-16$ & 94 & $1.52 \mathrm{ab}$ & $0.345 \mathrm{a}$ & $1.48 \mathrm{a}$ & 0.203 & $7.12 \mathrm{~d}$ & 72.8 \\
\hline \multirow{6}{*}{ Calcareous fill } & None & 0 & $1.35 \mathrm{~b}$ & $0.497 \mathrm{a}$ & $1.00 \mathrm{c}$ & $0.278 \mathrm{a}$ & $6.61 \mathrm{c}$ & $86.9 \mathrm{ab}$ \\
\hline & $24-0-11$ & 41.7 & $1.18 \mathrm{ab}$ & $0.195 \mathrm{bc}$ & $0.77 \mathrm{~d}$ & $0.270 \mathrm{ab}$ & $6.47 c$ & $75.8 \mathrm{~b}$ \\
\hline & $24-0-11$ & 83.4 & $1.42 \mathrm{a}$ & $0.151 \mathrm{c}$ & $0.92 \mathrm{~cd}$ & $0.218 \mathrm{~b}$ & $10.77 \mathrm{~b}$ & $77.3 \mathrm{~b}$ \\
\hline & 8-0-12 & 125 & $1.07 \mathrm{~b}$ & $0.259 \mathrm{~b}$ & $1.27 \mathrm{a}$ & $0.227 \mathrm{ab}$ & $13.55 \mathrm{~b}$ & $77.2 \mathrm{~b}$ \\
\hline & $8-0-12$ & 250 & $1.14 \mathrm{ab}$ & $0.174 \mathrm{bc}$ & $1.23 \mathrm{ab}$ & $0.230 \mathrm{ab}$ & $21.44 \mathrm{a}$ & $77.2 \mathrm{~b}$ \\
\hline & $0-0-16$ & 94 & $1.22 \mathrm{ab}$ & $0.482 \mathrm{a}$ & $1.03 \mathrm{bc}$ & $0.267 \mathrm{ab}$ & $13.39 \mathrm{~b}$ & $96.7 \mathrm{a}$ \\
\hline
\end{tabular}

${ }^{\mathrm{z}} 24-0-1 \mathrm{l}$ (24N-0P-9.2K contains mostly water soluble $\mathrm{N}$ and $\mathrm{K}$ plus insoluble Fe and $\mathrm{Mn}$, but no Mg or micronutrients); 8-0-12 (8N-0P-10K-4Mg contains controlled release $\mathrm{N}, \mathrm{K}$, and $\mathrm{Mg}$ plus water soluble micronutrients); 0-0-16 (0N-0P-13.3K-6Mg contains controlled release $\mathrm{K}$ and $\mathrm{Mg}$ plus water soluble micronutrients).

${ }^{\mathrm{y}} \mathrm{l} \mathrm{g} \cdot \mathrm{m}^{-2}=0.2048 \mathrm{lb} / 1000 \mathrm{ft}^{2}, \mathrm{l} \mu \mathrm{g} \cdot \mathrm{g}^{-1}=1 \mathrm{ppm}$.

${ }^{x}$ Means followed by different letters are significantly different at $P<0.05$ level using the Waller-Duncan $k$-ratio method.

"Nonsignificant at $P>0.05$. 
extremely low for all treatments in both soils with only the two 8-0-12 treatments on the sand soil producing foliage with Mn concentrations abovel $0 \mu \mathrm{g} \cdot \mathrm{g}^{-1}$. Jones et al. (1991) consider $\mathrm{Mn}$ concentrations below $40 \mu \mathrm{g} \cdot \mathrm{g}^{-1}$ to be deficient in this species.

Surinam cherry showed significant differences in leaf nutrient concentrations for all elements except $\mathrm{Mg}$ and $\mathrm{Fe}$ on the sand soil and all elements on the fill soil (Table 6). Phosphorus concentrations tended to be highest in those treatments that resulted in the least growth (controls and both rates of $0-0-16$ ) because of dilution effects. Foliar P concentrations for most other treatments were below the $0.21 \%$ threshold for deficiency in this species (Jones et al., 1991). Potassium concentrations were lowest in the treatments having the highest $\mathrm{N}: \mathrm{K}$ ratio (the $24-0-1 \mathrm{l}$ treatments). On the calcareous fill soil, leaf $\mathrm{Mg}$ concentrations were higher in the unfertilized controls and the high rate of $0-0-16$ than in the high rate of 24-0-11. Again, this was likely because of dilution as the high rate of 24-0-11 produced by far the largest plants and the unfertilized controls and both rates of 0-0-16 resulted in the smallest plants. Unfertilized control plants and those receiving the low rate of 24-0-11 had the lowest leaf $\mathrm{Mn}$ concentrations on both soil types, but both 0-0-16 treatments had similarly low Mn concentrations on the sand soil. Although visual Mn deficiency symptoms were not apparent on this species, all treatments in this study resulted in foliar Mn concentrations below the minimum $25 \mu \mathrm{g} \cdot \mathrm{g}^{-1} \mathrm{rec}-$ ommended for this species by Jones et al. (1991).

In conclusion, with the exception of ixora grown in sand soil, where $\mathrm{N}$-containing fertilizers of either type improved quality, fertilizer type and rate had little or no effect on overall plant quality of allamanda, ixora, or surinam cherry during the first 6 months following transplanting. Once established, plant quality of allamanda and surinam cherry was influenced by fertilizer type and rate on both soil types. The high rate of 24-0-11 consistently produced high quality plants of both species on both soil types, but equivalent quality was obtained with the low rate of 24-0 11 or either rate of 8-0-12 in all cases except for surinam cherry grown on fill soil. Thus, although high $\mathrm{K}, \mathrm{Mg}$, and micronutrient fertilizers are essential for palms growing in these same soils (Broschat, 2015; Broschat et al., 2008), these eudicot shrubs appear to grow just as well with less expensive turf fertilizers. Although plants grown on the calcareous fill soil were always smaller and more nutrient-deficient than those growing on the native sand soil, the types of nutrient deficiencies observed and plant responses to these fertilizer types were similar on both soil types. Thus, ornamental shrubs do not require different fertilization programs when grown on these two soil types in south Florida.

\section{Literature cited}

Broschat, T.K. 1979. Principal component analysis in horticultural research. HortScience 14:114-117.

Broschat, T.K. 2015. Fertilization of landscape palms to reduce nitrogen and phosphorus impacts on the environment. HortScience 50:469-473.

Broschat, T.K. and K.A. Moore. 2010. Effects of fertilization on the growth and quality of container-grown areca palm and chinese hibiscus during establishment in the landscape. HortTechnology 20:389394.

Broschat, T.K., D.R. Sandrock, M.L. Elliott, and E.F. Gilman. 2008. Effects of fertilizer type on quality and nutrient content of established landscape plants in Florida. HortTechnology 18:278-285.

Dickey, R.D. 1977. Nutritional deficiencies of woody ornamental plants used in Florida landscapes. Univ. Florida Agr. Expt. Sta. Bul. 791.

Gilman, E.F. 1987. Response of hibiscus to soil applied nitrogen. Proc. Florida State Hort. Soc. 100:356-357.

Gilman, E.F. 1988. Field grown hibiscus response to nitrogen rate. Proc. Florida State Hort. Soc. 101:99-101.

Gilman, E.F. and T.H. Yeager. 1990. Fertilizer type and nitrogen rate affects field-grown laurel oak and Japanese ligustrum. Proc. Florida State Hort. Soc. 103:370-372.

Gilman, E.F., T.H. Yeager, and D. Kent. 2000. Fertilizer rate and type impacts magnolia and oak growth in sandy landscape soil. J. Arboricult. 26:177-182.

Hach, C.C., B.K. Bowden, A.B. Koplove, and S.V. Brayton. 1987. More powerful peroxide Kjeldahl digestion method. J. Offic. Anal. Chem. 70:783-787.

Jones, J.B., Jr., B. Wolf, and H.A. Mills. 1991. Plant analysis handbook. MicroMacro Publ., Athens, GA.

Kuo, S. 1996. Phosphorus, p. 869-920. In: J.M. Bartels (ed.). Methods of soil analysis. Part 3. Chemical methods. Soil Sci. Soc. Amer., Madison, WI.

Mills, H.A. and J.B. Jones, Jr. 1996. Plant analysis handbook II. Micro-Macro Publ., Athens, GA.

Shober, A.L., K.A. Moore, N.G. West, C. Wiese, G. Hasing, G. Denny, and G.W. Knox. 2013. Growth and quality response of woody shrubs to nitrogen fertilization rates during landscape establishment in Florida. HortTechnology 23:898-904.

Struve, D.K. 2002. A review of shade tree nitrogen fertilization research in the United States. J. Arboricult. 28:252-263. 